\title{
逆性石献液中の細菌増殖の防止法について
}

\section{Prevention of the bacterial growth in quaternary ammonium germicide solutions.}

\author{
国立予防衞生研究所細菌部（指導，福見秀雄部長） \\ 藤、田 浩三 \\ Kōzo Fujita
}

Department of Bacteriology, National Institute of Health

\section{I. まえがき}

1935年逆性石䍄（以下 Q.A.C. と略記する）が Dom$\mathrm{agk}^{11}$ によって報告されるや，その殺菌効力の優㑧性及び 毒性が比較的低いとと，皮唐や粘膜に対する刺戟性が少 いこと等て，Wetzel ${ }^{2)}$ は早くも同年手術時の手指消毒に 用い, その後外傷の洗沙 ${ }^{3-5)}$, 灌注に, 又泌尿器科(,7), 産婦人科 ${ }^{81}$ 領域等の臨休面, 並びに食品衙生関係方面の 器具の消毒等9,10) に使用され，その用途は広範囲にわた って開拓される様になった。その後ての殺菌効力につい ては種くの報告が見られるが, 1951年 Loubury ${ }^{111}$ は Q.

A.C. 液より Pseudomonas pyocyanea 分離し，これが 感染源となることを警告し，ての原因としてコルク栓を 考え殺菌後使用すべきととを述べている。

1958年の British Medical Journal ${ }^{121}$ 紙上には “Bacteria in Antiseptic Solution" の中て Pseudomonas pyocyanea による菌血症の危険について注意している。中野 ${ }^{13}$ は各 種の化学構造を異にする Q.A.C. より Achromobacter 及び Alcaligenes に属する菌を分離し，乙れ等の細菌は 何等かの原因で污染されたまま殺菌せられずに生存して いるのてはなくて, Q.A.C. 自体を栄養源として発育し 得る可能性を見出し報告している。Achromobacter に属 する細菌は相磯14)によって腐敗菌として広範な研究がな され, Spanswick ${ }^{15}$ ) 卵の徽臭の原因として, Haines ${ }^{16)}$ は変敗した肉から原因菌として分離して抢り, 食品衞生 上重要な意義を有している。 Alcaligenes 属の 細菌は動 物の腸管に寄棲していることは良く知られて抢り，Bergey's Determinative Bacteriology ${ }^{17)}$ によれば，何れも非 病原性菌であると記載されているが，若し多量の 菌が Q.A.C. 液か, これて処理された器具を介して, 創傷,
食品等に持ち来たらされたならば，清浄に保つ可き所に 六えって污染の原因を消毒薬によって作ることになるの ではなかららか。しかし，特異な性状と長所を有し，各 方面で有意且つ広範に利用されている消毒薬を，とのた めに使用を禁ずるととは残念に思われるし，とのまま放 置するととは更に非常な危険があると考える。そこで， 著者はこれ等の危険性を防止するために，Q.A.C. の長 所を阻害しない他の薬物の添加によって，この中での細 菌発育を阻止しょうと考え, 実験を行ったのでここに報 告する。

\section{II. 分離した細菌の熱抵抗性}

Loubury ${ }^{111}$ は Q.A.C. 液が生菌で污染されているとの 問題をとりあげた中で，薬液を入れる小瓶を使用前に隇 菌することを指示しているが，著者は Q.A.C. 中で発育 する菌が10\% Q.A.C. 液中, 或いは普通ブイョン中でぞ の位の熱抵抗性を有しているかを知る目的で次の実験を 行った。

\section{a) 実験法}

使用した Q.A.C. 液は Methyl-dodecyl-benzyl-trimethyl-ammonium chloride (以下MD B A C と略記する), Benzethonium chloride (以下 B T C と略記する), 及び Benzalkonium chloride (以下 B A C と略記する) の三種 で，てれ等を $10 \%$ に調製し，全く無菌であること並びに 菌が発育し得ることを確かめた後に使用した。

以下行った実験は全部同一薬物を用いた。使用した細 菌は中野 ${ }^{13)}$ により分離された Alcaligenes 属のものよ り一株 (K株, Alcaligenes foecalis と考えられる), Achromobacter 属のものより一株 (A-39株, Achromobacter guttatus と考元られる)を選んだ。 
表 1 分政した細菌の整抵抗性

\begin{tabular}{|c|c|c|c|c|c|c|c|c|c|c|c|c|c|c|c|}
\hline & $\begin{array}{l}\text { 温度 } \\
\left({ }^{\circ} \mathrm{C}\right)\end{array}$ & 菌名 時間 & $15^{\text {秒 }}$ & $30^{\prime \prime}$ & $60^{\prime \prime}$ & $150^{\prime \prime}$ & $5^{\text {分 }}$ & $10^{\prime \prime}$ & $15^{\prime \prime}$ & $30^{\prime \prime}$ & $1^{\text {時 }}$ & $2^{\prime \prime}$ & $3^{\prime \prime}$ & $4^{\prime \prime}$ & $24^{\prime \prime}$ \\
\hline \multirow{3}{*}{ 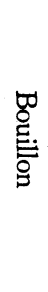 } & 40 & $\begin{array}{c}\mathrm{A}-39 \\
\mathrm{~K}\end{array}$ & $\begin{array}{l}+ \\
+\end{array}$ & $\begin{array}{l}+ \\
+\end{array}$ & $\begin{array}{l}+ \\
+\end{array}$ & $\begin{array}{l}+ \\
+\end{array}$ & $\begin{array}{l}+ \\
+\end{array}$ & $\begin{array}{l}+ \\
+\end{array}$ & $\begin{array}{l}+ \\
+\end{array}$ & $\begin{array}{l}+ \\
+\end{array}$ & $\begin{array}{l}+ \\
+\end{array}$ & $\begin{array}{l}+ \\
+\end{array}$ & $\begin{array}{l}+ \\
+\end{array}$ & $\begin{array}{l}+ \\
+\end{array}$ & $\begin{array}{l}+ \\
+\end{array}$ \\
\hline & 50 & $\begin{array}{c}A-39 \\
K\end{array}$ & $\begin{array}{l}+ \\
+\end{array}$ & $\begin{array}{l}+ \\
+\end{array}$ & $\begin{array}{l}+ \\
+\end{array}$ & $\begin{array}{l}+ \\
+\end{array}$ & $\begin{array}{l}+ \\
+\end{array}$ & $\begin{array}{l}+ \\
+\end{array}$ & $\begin{array}{l}+ \\
+\end{array}$ & $\begin{array}{l}+ \\
+\end{array}$ & $\begin{array}{l}+ \\
+\end{array}$ & $\begin{array}{l}+ \\
+\end{array}$ & $\begin{array}{l}+ \\
+\end{array}$ & $\begin{array}{l}+ \\
+\end{array}$ & $\begin{array}{l}+ \\
+\end{array}$ \\
\hline & 60 & $\begin{array}{c}A-39 \\
K\end{array}$ & $\begin{array}{l}+ \\
+\end{array}$ & $\begin{array}{l}+ \\
+\end{array}$ & $\begin{array}{l}+ \\
+\end{array}$ & + & + & + & $\begin{array}{l}+ \\
-\end{array}$ & - & - & $\begin{array}{l}- \\
-\end{array}$ & - & $\begin{array}{l}- \\
-\end{array}$ & - \\
\hline \multirow{3}{*}{ 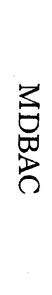 } & 40 & $\begin{array}{c}A-39 \\
K\end{array}$ & $\begin{array}{l}+ \\
+\end{array}$ & $\begin{array}{l}+ \\
+\end{array}$ & $\begin{array}{l}+ \\
+\end{array}$ & + & + & + & $\begin{array}{l}+ \\
-\end{array}$ & + & + & $\begin{array}{l}+ \\
-\end{array}$ & + & + & + \\
\hline & 50 & $\begin{array}{c}A-39 \\
K\end{array}$ & $\bar{t}$ & $\overline{-}$ & - & - & - & - & - & - & - & - & - & - & - \\
\hline & 60 & $\begin{array}{c}\mathrm{A}-39 \\
\mathrm{~K}\end{array}$ & - & $\begin{array}{l}- \\
-\end{array}$ & $\underline{-}$ & - & - & - & - & - & - & - & - & $\begin{array}{l}- \\
-\end{array}$ & - \\
\hline \multirow{2}{*}{ 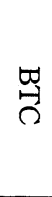 } & 40 & $\begin{array}{c}A-39 \\
K\end{array}$ & $\begin{array}{l}+ \\
+\end{array}$ & $\begin{array}{l}+ \\
+\end{array}$ & $\begin{array}{l}+ \\
+\end{array}$ & $\begin{array}{l}+ \\
+\end{array}$ & $\begin{array}{l}+ \\
+\end{array}$ & $\begin{array}{l}+ \\
+\end{array}$ & $\begin{array}{l}+ \\
+\end{array}$ & $\begin{array}{l}+ \\
+\end{array}$ & $\begin{array}{l}+ \\
+\end{array}$ & $\begin{array}{l}+ \\
-\end{array}$ & $\begin{array}{l}+ \\
-\end{array}$ & $\begin{array}{l}+ \\
-\end{array}$ & $\begin{array}{l}+ \\
-\end{array}$ \\
\hline & 50 & $\begin{array}{c}A-39 \\
K\end{array}$ & - & - & - & - & - & - & - & - & - & $\begin{array}{l}- \\
-\end{array}$ & - & - & - \\
\hline \multirow{2}{*}{ 䒠 } & 40 & $\begin{array}{c}A-39 \\
K\end{array}$ & $\begin{array}{l}+ \\
+\end{array}$ & $\begin{array}{l}+ \\
+\end{array}$ & $\begin{array}{l}+ \\
-\end{array}$ & + & - & - & - & - & - & - & - & - & - \\
\hline & 50 & $\begin{array}{c}A-39 \\
K\end{array}$ & - & - & - & - & - & - & - & - & - & - & - & - & - \\
\hline
\end{tabular}

MDBAC : Methyl-dodecyl-benzyl-trimethyl ammonium chloride

BTC : Benzethonium chloride

BAC : Benzalkonium chloride

まず10\% Q.A.C. 液及びブイヨン培地をそれぞれ $10 \mathrm{cc}$ 宛大試験管に分注し， 恒温槽に入れて 所定の温度に保 つ, この中に供試菌のブイョン培養をしたものを $1 \mathrm{cc}$ 加えて良く混和する。一定時間経過毎に一白金耳宛取出 して普通ブイヨンに後培養を行い, $37^{\circ} \mathrm{C}$ に保って観察 し，菌の発育をもって陽性とした。

\section{b) 実験成績}

成績は表 1 に示すと抢りで，ブイョン中では菌は両

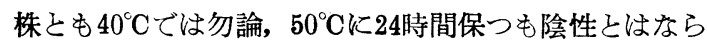
す， $60^{\circ} \mathrm{C} て ゙ ~ A-39$ 株は 30 分で，K株恃 150 秒後にはじめ て陰性となり，熱に対して相当抵抗性があることが認め られた。Q.A.C. 液中では A-39株はMD B A C と B T C に注加したときには $40^{\circ} \mathrm{C} 24$ 時間経過後も陽性の成績が得 られたが, B A C 中では 5 分以内に殺菌されて了うのが 見られた。K株はてれょり熱汶対して弱く, MD B A C
中では 150 秒以内, B T C 中では 1 時間まで陽性である が， 2 時間では死滅している。 B A C 中では 1 分以内に 陰性の成績となるのが見られた。 $50^{\circ} \mathrm{C}$ の場合にはMD B $\mathrm{A} \mathrm{C}$ 中でK株が僅かに30秒まで検出されたが, 他の二種 のQA C液中では15秒以内に両株上も殺菌された。ブイ ヨン培地中, 或いは Q.A.C. 液中を問わず, Alcaligenes に属する株の方が, Achromobacter に属するものより熱 に対して弱い傾向が見られ，ブイョン培地中では比较的 高温に長く耐えるが, Q.A.C. 液中では温度の上昇とと もに速やかに死减することが判明した。なお菌液注加等 に際しての温度の低下は $0.5^{\circ} \mathrm{C}$ 以内であった。

\section{III. 分離菌の石炭酸ならびにクレゾール に対する抵抗性}

a) 実験法 
実験は厚生省編の衞生検査指針中の消毒薬検查指針に 準拠して行った。即ち石炭酸並びに局方クレゾール石検 液を所定の濃度に稀釈し, 作用武験管に10cc宛分注して

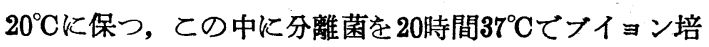
養したものを $1 \mathrm{cc}$ 宛加え，5 分，10分及び15分の 3 回後 培養を行った。使用した菌は中野が 報告した全株を用 い, 対照としてはチフス菌を用いた。

\section{表 2 石炭酸，クレソ゚ールに対する抵抗性} 石炭酸

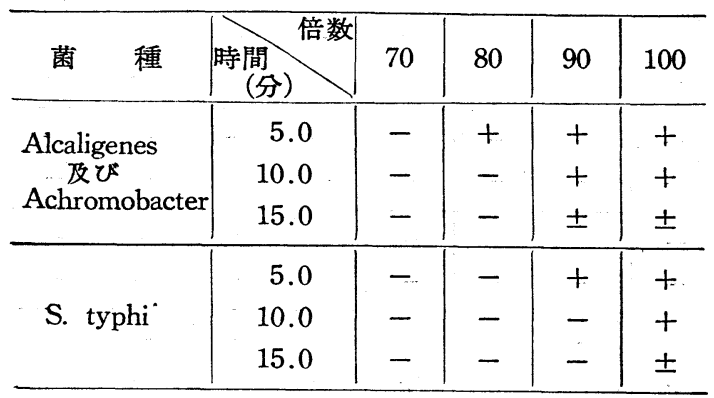

局方クレン゙ール石战液

\begin{tabular}{|c|c|c|c|c|c|}
\hline 菌 種 & \begin{tabular}{|c|c|c|} 
時間 $_{(\text {分 })}$ \\
倍
\end{tabular} & 100 & 150 & 200 & 250 \\
\hline & 5.0 & + & + & + & + \\
\hline \multirow[t]{2}{*}{ Alcaligenes } & 10.0 & - & + & + & + \\
\hline & 15.0 & - & - & + & + \\
\hline \multirow{3}{*}{ Achromobacter } & 5.0 & - & + & + & + \\
\hline & 10.0 & - & - & - & + \\
\hline & 15.0 & - & - & - & \pm \\
\hline \multirow{3}{*}{ S. typhi } & 5.0 & - & + & + & + \\
\hline & 10.0 & - & - & + & + \\
\hline & 15.0 & - & - & - & $\therefore$ \\
\hline
\end{tabular}

表中士は菌株により十の場合と, 一の場合か あつたととを示す。

\section{b) 実験成績}

成績は表 2 の如く，石炭酸に対しては，Alcaligenes 㞋び Achromobacter に属する両種ともほとんど差異が 認められず, チフス菌 (TD株) 功石炭酸に対する抵抗 性より僅かに強い㑯向を有することが見られるのみであ った。局方クレソール石䍄液に対しては Achromobacter に属する菌の方が Alcaligenes に属する菌よりやや強い 抵抗性を有し；テフス菌は両者の中間に位するのが見ら れた。

この成績より見れば, 分離菌は Q.A.C. に対して感受
性が低いにもかかわらず, 芳香族の消毒薬に対してはそ の感受性は湾とんぞチフス菌と同様であった。

\section{Q.A.C. に添加する発育阻止薬物の選定}

\section{a) 実験法}

この実験で Q.A.C.に種々の薬物を添加して，菌を 接種し, 発育の有無を確かめるために Stephenson and Whetham の合成培地中(踋)の炭素源であるクェン酸ナ トリウムを除き，かわりに10\%の割になる様に前記三種 のQ.A.C. を夫々加え，これに種々の薬物を所定の濃度 に添加したものを 5 cc宛中試験管に分注した。ついで前 項で使用したと同一の菌株をあらかじめ合成培地で $37^{\circ} \mathrm{C}$ 20時間培養し，乙の菌液を一白金耳宛接種して， $37^{\circ} \mathrm{C}$ K て培養, 菌の発育の有無を中間判定を行いながら10日後 まで観察した。

細菌の発育阻止に用いた添加薬物は， Q.A.C. が有し ている長所でる無色，無臭，水樣透明で毒性が低いこ と等を阻害しないものであるととが必要なので，実験に 使用したものの約半数は厚生省より指定されている合成 保存料, 着色料, 殺菌料等より選んだ。これは毒性の点 で非常に安全であると考えて良かろう。

使用濃度は表 3 に示されているが, 食品添加物の場合 には指定された 濃度を参考とし，大多数の場合，乙れ が最高濃度となるよう添加量を定めた。即与硫酸銅では クリンピース等の 着色料として $0.1 \mathrm{~g} / \mathrm{kg}$ を最高限とし て指示されている。保存料としてのサルチル酸は酒には $0.25 \mathrm{~g} / l$ ，酢には $0.06 \mathrm{~g} / l$ k，安息香酸及び安息香酸ナト リウムは前者に换算して, 嶈油, 清凉领料等に $0.6 \mathrm{~g} / \mathrm{kg}$ ソルビン酸ナトリウムは， 万にには $2 \mathrm{~g} / \mathrm{kg}$ ，煮豆には 1 $\mathrm{g} / \mathrm{kg}$ ，パラオキシ安息香酸エチルェステル，ブチルエス テル及びプロピルェステルは共にパラオキシ安息香酸と してソースに $0.2 \mathrm{~g} / l$ 使用して良いことになっている。 殺菌料としてニトロフラン並びにニトロフリルアクリル 酸アミドが指定されているが, 前者は $0.005 \mathrm{~g} / \mathrm{kg}$, の添 加孝許可せられて招り，後者は魚練製品に $0.02 \mathrm{~g} / \mathrm{kg}$, 乾 魚に $0.001 \mathrm{~g} / \mathrm{kg}$, 豆腐に $0.005 \mathrm{~g} / \mathrm{kg}$ の添加を 許されて いる。その他の薬物の濃度の決定は区々て，Lovell ${ }^{187}$ は10\%アセトンに1000倍の割にQ.A.C.を加えたチンキ を用いているため添加量も $10 \%, 5 \%, 1 \%$ とし，アル

\begin{tabular}{|c|c|c|c|}
\hline \multicolumn{4}{|c|}{ 脚註 : Stephenson and } \\
\hline $\mathrm{KH}_{2} \mathrm{PO}_{4}$ & $1.0 \mathrm{~g}$ & $\mathrm{MgSO}_{4} \cdot 7 \mathrm{H}_{2} \mathrm{O}$ & $0.7 \mathrm{~g}$ \\
\hline $\mathrm{NaCl}$ & $1.0 \mathrm{~g}$ & $\left(\mathrm{NH}_{4}\right)_{2} \mathrm{HPO}_{4}$ & $4.0 \mathrm{~g}$ \\
\hline FeSO, & $0.03 \mathrm{~g}$ & クエン酸ナト & $5.0 \mathrm{~g}$ \\
\hline 蒸溜水 & $1000 \mathrm{cc}$ & 7.0 & \\
\hline
\end{tabular}


表 3 薬物添加による発育阻止

\begin{tabular}{|c|c|c|c|c|c|c|c|c|c|c|c|c|c|c|c|}
\hline \multirow[b]{2}{*}{ 添加薬物 } & \multirow{2}{*}{$\mid \begin{array}{c}\text { Q.A.C. } \\
\text { 菌株品 } \\
\text { 濃 } \\
\text { 度 }(\%)\end{array}$} & \multicolumn{2}{|c|}{ MDBAC } & \multicolumn{2}{|c|}{ BTC } & \multicolumn{2}{|c|}{$\mathrm{BAC}$} & \multirow[b]{2}{*}{ 添加薬物 } & \multirow{2}{*}{$\begin{array}{c}\text { Q.A.C. } \\
\text { 菌株名 } \\
\text { 濃 } \\
\text { 度 }(\%)\end{array}$} & \multicolumn{2}{|c|}{ MDBAC } & \multicolumn{2}{|c|}{ BTC } & \multicolumn{2}{|c|}{$\mathrm{BAC}$} \\
\hline & & A-39 & $\mathrm{K}$ & A-39 & $\mathrm{K}$ & A-39 & $\mathrm{K}$ & & & A-39 & $\mathrm{K}$ & A-93 & $\mathrm{K}$ & A-93 & $\mathrm{K}$ \\
\hline アセトン & $\begin{array}{r}10 \\
5 \\
1\end{array}$ & $\begin{array}{l}- \\
- \\
+\end{array}$ & $\begin{array}{l}- \\
- \\
+\end{array}$ & $\begin{array}{l}- \\
+ \\
+ \\
\end{array}$ & $\begin{array}{l}- \\
- \\
+ \\
\end{array}$ & $\begin{array}{l}+ \\
+ \\
+ \\
\end{array}$ & $\begin{array}{l}+ \\
+ \\
+ \\
\end{array}$ & サリチル酸 & $\begin{array}{l}0.1 \\
0.05 \\
0.025\end{array}$ & $\begin{array}{l}+ \\
+ \\
+\end{array}$ & $\begin{array}{l}+ \\
+ \\
+\end{array}$ & $\begin{array}{l}+ \\
+ \\
+\end{array}$ & $\begin{array}{l}+ \\
+ \\
+\end{array}$ & $\begin{array}{l}- \\
+ \\
+\end{array}$ & $\begin{array}{l}- \\
+ \\
+\end{array}$ \\
\hline アルコール & $\begin{array}{r}10 \\
5 \\
1 \\
\end{array}$ & $\begin{array}{l}- \\
- \\
+\end{array}$ & $\begin{array}{l}- \\
- \\
+\end{array}$ & $\begin{array}{l}- \\
- \\
+\end{array}$ & $\begin{array}{l}- \\
- \\
+\end{array}$ & $\begin{array}{l}- \\
+ \\
+\end{array}$ & $\begin{array}{l}- \\
+ \\
+\end{array}$ & ホルよ & $\begin{array}{l}0.6 \\
0.06 \\
0.006 \\
\end{array}$ & $\begin{array}{l}- \\
- \\
-\end{array}$ & $\begin{array}{l}- \\
- \\
+\end{array}$ & $\begin{array}{l}- \\
- \\
-\end{array}$ & $\begin{array}{l}- \\
- \\
+\end{array}$ & $\begin{array}{l}- \\
- \\
-\end{array}$ & $\begin{array}{l}- \\
- \\
-\end{array}$ \\
\hline 砂 & $\begin{array}{l}1 \\
0.5 \\
0.25 \\
\end{array}$ & $\begin{array}{l}- \\
- \\
-\end{array}$ & $\left|\begin{array}{l}- \\
- \\
+\end{array}\right|$ & $\begin{array}{l}- \\
- \\
-\end{array}$ & $\left|\begin{array}{l}- \\
- \\
-\end{array}\right|$ & $\begin{array}{l}- \\
- \\
-\end{array}$ & $\begin{array}{l}- \\
- \\
+\end{array}$ & 安 息 香 酸 & $\begin{array}{l}0.6 \\
0.06 \\
0.006 \\
\end{array}$ & $\begin{array}{l}- \\
+ \\
H\end{array}$ & $\begin{array}{l}+ \\
+ \\
+\end{array}$ & $\begin{array}{l}- \\
+ \\
H\end{array}$ & $\begin{array}{l}- \\
+ \\
+\end{array}$ & $\begin{array}{l}- \\
- \\
-\end{array}$ & $\begin{array}{l}- \\
- \\
-\end{array}$ \\
\hline $\mathrm{Na}_{2} \mathrm{HPO}_{4}$ & $\begin{array}{l}1 \\
0.5 \\
0.25\end{array}$ & $\begin{array}{l}+ \\
+ \\
+\end{array}$ & $\begin{array}{l}+ \\
+ \\
+\end{array}$ & $\begin{array}{l}+ \\
+ \\
+\end{array}$ & $\begin{array}{l}+ \\
+ \\
+\end{array}$ & $\begin{array}{l}- \\
+ \\
+\end{array}$ & $\begin{array}{l}+ \\
+ \\
+\end{array}$ & $\begin{array}{l}\text { 安息香酸 } \\
\text { ナトリウム }\end{array}$ & $\begin{array}{l}0.6 \\
0.06 \\
0.006 \\
\end{array}$ & $\begin{array}{l}\text { m } \\
\text { W } \\
H\end{array}$ & $\begin{array}{l}+ \\
+ \\
+\end{array}$ & $\begin{array}{l}+ \\
+ \\
+\end{array}$ & $\begin{array}{l}+ \\
+ \\
+\end{array}$ & $\begin{array}{l}- \\
+ \\
+\end{array}$ & $\begin{array}{l}- \\
- \\
+\end{array}$ \\
\hline $\mathrm{Na}_{4} \mathrm{P}_{2} \mathrm{O}_{7}$ & $\begin{array}{l}1 \\
0.5 \\
0.25\end{array}$ & $\begin{array}{l}+ \\
+ \\
+\end{array}$ & $\begin{array}{l}+ \\
+ \\
+\end{array}$ & $\begin{array}{l}+ \\
+ \\
+\end{array}$ & $\begin{array}{l}+ \\
+ \\
+\end{array}$ & $\begin{array}{l}+ \\
+ \\
+\end{array}$ & $\begin{array}{l}- \\
+ \\
+\end{array}$ & $\begin{array}{l}\text { ソルビン酸 } \\
\text { ナトリウム }\end{array}$ & $\begin{array}{l}0.4 \\
0.2 \\
0.1\end{array}$ & $\begin{array}{l}- \\
+ \\
+\end{array}$ & $\left|\begin{array}{l}- \\
- \\
+\end{array}\right|$ & $\begin{array}{l}- \\
- \\
+\end{array}$ & - & $\begin{array}{l}- \\
- \\
-\end{array}$ & $\begin{array}{l}- \\
- \\
-\end{array}$ \\
\hline $\mathrm{Na}_{3} \mathrm{PO}_{4}$ & $\begin{array}{l}1 \\
0.5 \\
0.25\end{array}$ & $\begin{array}{l}+ \\
+ \\
+\end{array}$ & $\begin{array}{l}+ \\
+ \\
+\end{array}$ & $\begin{array}{l}+ \\
+ \\
+\end{array}$ & $\begin{array}{l}+ \\
+ \\
+\end{array}$ & $\begin{array}{l}+ \\
+ \\
+\end{array}$ & $\begin{array}{l}- \\
+ \\
+\end{array}$ & $\begin{array}{l}\text { パラォキシ } \\
\text { 安息香酸 } \\
\text { エチルェステル }\end{array}$ & $\begin{array}{l}0.02 \\
0.01 \\
0.005\end{array}$ & $\begin{array}{l}+ \\
+ \\
+\end{array}$ & $\begin{array}{l}+ \\
+ \\
+\end{array}$ & $\begin{array}{l}+ \\
+ \\
+\end{array}$ & $\begin{array}{l}+ \\
+ \\
+\end{array}$ & $\begin{array}{l}+ \\
+ \\
+\end{array}$ & $\begin{array}{l}+ \\
+ \\
+\end{array}$ \\
\hline アクทフラピン & $\begin{array}{l}1 \\
0.3 \\
0.1 \\
\end{array}$ & $\begin{array}{l}- \\
- \\
+\end{array}$ & $\mid \begin{array}{l}- \\
- \\
-\end{array}$ & $\begin{array}{l}- \\
- \\
-\end{array}$ & $\begin{array}{l}- \\
- \\
+\end{array}$ & $\begin{array}{l}- \\
- \\
-\end{array}$ & $\begin{array}{l}- \\
- \\
-\end{array}$ & $\begin{array}{c}\prime \prime \\
\text { ブチルエステル }\end{array}$ & $\begin{array}{l}0.02 \\
0.01 \\
0.005\end{array}$ & $\begin{array}{l}+ \\
+\end{array}$ & $\begin{array}{l}+ \\
+ \\
+\end{array}$ & $\begin{array}{l}+ \\
+ \\
+\end{array}$ & $\begin{array}{l}+ \\
+\end{array}$ & $\begin{array}{l}+ \\
+ \\
+\end{array}$ & $\begin{array}{l}+ \\
+ \\
+\end{array}$ \\
\hline 硝 酸 銀 & $\begin{array}{l}1 \\
0.5 \\
0.25 \\
\end{array}$ & $\begin{array}{l}- \\
- \\
-\end{array}$ & \begin{tabular}{|l|}
- \\
- \\
-
\end{tabular} & $\begin{array}{l}- \\
- \\
-\end{array}$ & $\begin{array}{l}- \\
- \\
-\end{array}$ & $\begin{array}{l}- \\
- \\
-\end{array}$ & $\begin{array}{l}- \\
- \\
-\end{array}$ & $\begin{array}{c}\prime \prime \\
\text { プロピルエステル }\end{array}$ & $\begin{array}{l}0.02 \\
0.01 \\
0.005 \\
\end{array}$ & $\begin{array}{l}+ \\
+ \\
+\end{array}$ & $\begin{array}{l}+ \\
+ \\
+\end{array}$ & $\begin{array}{l}+ \\
+ \\
+\end{array}$ & $\begin{array}{l}+ \\
+ \\
+\end{array}$ & $\begin{array}{l}+ \\
+ \\
+\end{array}$ & $\begin{array}{l}- \\
+ \\
+\end{array}$ \\
\hline 硫酸亜鉛 & $\begin{array}{l}0.5 \\
0.25 \\
\end{array}$ & $\begin{array}{l}- \\
- \\
+\end{array}$ & \begin{tabular}{|l|}
- \\
- \\
+
\end{tabular} & $\begin{array}{l}- \\
- \\
+\end{array}$ & $\begin{array}{l}- \\
- \\
+\end{array}$ & $\begin{array}{l}- \\
+ \\
+\end{array}$ & $\begin{array}{l}- \\
- \\
-\end{array}$ & $\begin{array}{l}\text { ニトロフทル } \\
\text { アクシル酸 } \\
\text { ア ミ }\end{array}$ & $\begin{array}{l}0.01 \\
0.005 \\
0.0025\end{array}$ & $\begin{array}{l}- \\
- \\
+\end{array}$ & $\mid \begin{array}{l}- \\
- \\
-\end{array}$ & $\begin{array}{l}- \\
- \\
-\end{array}$ & $\begin{array}{l}- \\
- \\
-\end{array}$ & $\begin{array}{l}- \\
- \\
+\end{array}$ & $\begin{array}{l}- \\
- \\
+\end{array}$ \\
\hline 硫 酸 銅 & $\begin{array}{l}0.3 \\
0.15 \\
0.075 \\
\end{array}$ & $\begin{array}{l}- \\
+ \\
+\end{array}$ & $\begin{array}{l}- \\
+ \\
+\end{array}$ & $\begin{array}{l}- \\
+ \\
+\end{array}$ & $\begin{array}{l}- \\
+ \\
+ \\
\end{array}$ & $\begin{array}{l}- \\
- \\
-\end{array}$ & $\begin{array}{l}- \\
- \\
+\end{array}$ & ニトロフラゾン & $\begin{array}{l}0.001 \\
0.0005 \\
0.00025\end{array}$ & $\begin{array}{l}+ \\
+ \\
+\end{array}$ & $\begin{array}{l}- \\
+ \\
+\end{array}$ & $\begin{array}{l}+ \\
+ \\
+\end{array}$ & $\begin{array}{l}+ \\
+ \\
+ \\
\end{array}$ & $\begin{array}{l}+ \\
+ \\
+\end{array}$ & $\begin{array}{l}+ \\
+ \\
+\end{array}$ \\
\hline $\mathrm{Ca}(\mathrm{OH})_{2}$ & $\begin{array}{l}0.1 \\
0.05 \\
0.025 \\
\end{array}$ & $\begin{array}{l}- \\
+ \\
+\end{array}$ & $\begin{array}{l}- \\
- \\
-\end{array}$ & $\begin{array}{l}+ \\
+ \\
+\end{array}$ & $\begin{array}{l}- \\
- \\
-\end{array}$ & $\begin{array}{l}+ \\
+ \\
+\end{array}$ & $\begin{array}{l}+ \\
+ \\
+\end{array}$ & $\exists \quad-r$ & $\begin{array}{c}100 \mathrm{ppm} \\
10 " \prime \\
1 " \\
\end{array}$ & $\begin{array}{l}- \\
- \\
-\end{array}$ & $\begin{array}{l}- \\
+ \\
+\end{array}$ & $\begin{array}{l}- \\
- \\
+\end{array}$ & $\begin{array}{l}- \\
- \\
-\end{array}$ & $\begin{array}{l}+ \\
+ \\
+\end{array}$ & $\begin{array}{l}+ \\
+ \\
+ \\
\end{array}$ \\
\hline 酸 & $\begin{array}{l}0.1 \\
0.05 \\
0.025\end{array}$ & $\begin{array}{l}+ \\
+ \\
+\end{array}$ & $\begin{array}{l}+ \\
+ \\
+\end{array}$ & $\begin{array}{l}+ \\
+ \\
+\end{array}$ & $\begin{array}{l}+ \\
+ \\
+\end{array}$ & $\begin{array}{l}+ \\
+ \\
+\end{array}$ & $\begin{array}{l}+ \\
+ \\
+\end{array}$ & $\begin{array}{l}\text { 次 亜塩 素 } \\
\text { 酸ナトทゥム }\end{array}$ & $\begin{array}{rr}100 & \prime \prime \\
10 & \prime \prime \\
1 & \prime \prime\end{array}$ & $\begin{array}{l}- \\
- \\
-\end{array}$ & $\begin{array}{l}- \\
+ \\
+\end{array}$ & $\begin{array}{l}- \\
- \\
+\end{array}$ & $\begin{array}{l}- \\
- \\
-\end{array}$ & $\begin{array}{l}+ \\
+ \\
+\end{array}$ & $\begin{array}{l}+ \\
+ \\
+\end{array}$ \\
\hline
\end{tabular}

MDBAC : Methyl-dodecyl-benzyl-trimethyl ammonium chloride BTC: Benzethonium chloride

$\mathrm{BAC}$ : Benzalkonium chloride 
コールはこれに準じて添加した。碱砂やリン酸ナトリウ ム等は Molner ${ }^{19}$ による Pseudomonas pyocyanea k関 する示唆により濃度を定めた。アクリフラビンは常用量 を，ホルムアルデビドは血清及びトキソイドには $0.02 \%$ 以下の含有を許可されて居り, ヨード, 次亜塩素酸ナト リウムは殺菌効力検查時に通常使用されている濃度とし た。

\section{b) 実験成績}

表 3 に示す如く, アセトンはアルコールに比してやや 効果が少く, B A C に添加した場合には10\%であっても 発育を阻止し得ず，アルコールでも10\%以下では危険な ととが見られた。リン酸三ナトリウムは $1 \%$ 添加ではほ とんぞ効果がなく，硼砂は $0.5 \%$ 添加すれば有效である ととがわかった。アクリフラビンは $0.3 \%$ で效力を有し た。硝酸銀は $0.25 \%$ 添加でも菌の発育は見られなかっ たがQ.A.C.に多量の沈澼を掞しし，硫酸重鉛及び硫酸 銅も全く同様であって，有効な手段とは考元られなかっ た。水酸化カルシウムは B A C k添加した時を除き K株
に対しては 0.075\%であ效力があったが，A-39株に対し ては效果がうすかった。硼酸，サリチル酸は使用した濃

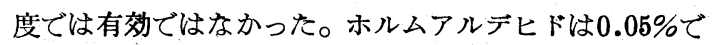
効果があり，特有な臭気を除けば優秀なもののうちに入 るものと考えられた。安息香酸及びそのナトリウム塩は Q.A.C.に添加すると非常に発育促進的に働き, 菌の増 殖度は他の添加薬に見られないほど高く, 培地は菌の発 育により著しく混濁した。ソルビン酸ナトリウムは比較 的低濃度ではやや発育促進的に働くが，0.2\%以上にな れば阻止的に㗢いた。パラオキシ安息香酸はェチルェス テル, ブチルェステル, プロピルエステル共に0.02\%で は発育阻止的に働かず，効果は認められなかった。二ト ロフリルアクリル酸アミドは $0.005 \%$ 添加により発育 を阻止したが、ニトロフラゾンは $0.001 \%$ で発育学阻 止し得なかった。次亜塩素酸ナトリウムは $100 \mathrm{ppm}$ 添 加しても発育が見られた場合があり，ヨードも全く同様 な状態を呈した。特に低濃度の場合には後者は消費され て脱色するのが見られた。

表 4 薬物添加後の逆性石领の性状

\begin{tabular}{|c|c|c|c|c|c|c|c|}
\hline Q.A.C. & 添 加 薬 物 & 添加量 & $\mathrm{pH}$ & $\begin{array}{l}\text { 石炭 } \\
\text { 酸係数 }\end{array}$ & 色 調 & 透明度 & 臭 \\
\hline \multirow{7}{*}{$\begin{array}{l}\text { Benzethonium } \\
\text { chloride }\end{array}$} & 照 & な し & 6.4 & 40 & 無 色 & 透 明 & \multirow{4}{*}{$\begin{array}{l}\text { 無 } \\
\text { ホル 臭 } \\
\text { アルンン臭: } \\
\text { アルール臭: }\end{array}$} \\
\hline & 砂 & $0.5 \%$ & 8.6 & 43 & $\prime \prime$ & $\prime \prime$ & \\
\hline & ホルムアルデヒド & $0.1 \%$ & 6.4 & 40 & "l & $\prime \prime$ & \\
\hline & $ア ル \geq-ル$ & $10 \%$ & 6.2 & 43 & $\prime \prime$ & $\prime \prime-$ & \\
\hline & アクリフラビン & $0.3 \%$ & 6.4 & 40 & 茶褐色 & 微＼cjkstart濁 & 無 \\
\hline & 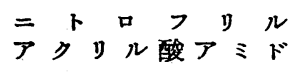 & $0.01 \%$ & 6.4 & 40 & 淡黄色 & 透 明 & "l \\
\hline & ソルビン酸ナトリゥム & $0.4 \%$ & 6.8 & 43 & 落葉色 & 微＼cjkstart濁 & " \\
\hline \multirow{7}{*}{$\begin{array}{l}\text { Methyl-dodecyl- } \\
\text { benzyl-trimethyl } \\
\text { ammodium } \\
\text { chloride }\end{array}$} & 照 & な ᄂ & 6.4 & 40 & 無 色 & 透 明 & 無 \\
\hline & 嗍 ‥ 砂 & $0.5 \%$ & 8.6 & 40 & $\prime \prime$ & $\prime \prime$ & \multirow{6}{*}{ 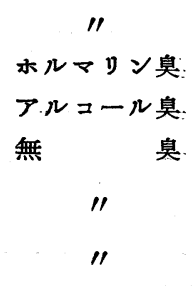 } \\
\hline & ホルムアルデヒド & $0.1 \%$ & 6.4 & 40 & $" \prime$ & " & \\
\hline & $ア ル \geq-ル$ & $10 \%$ & 6.2 & 43 & $\prime \prime$ & $\prime \prime$ & \\
\hline & 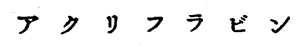 & $0.3 \%$ & 7.0 & 40 & 茶褐色 & 微 濁 & \\
\hline & 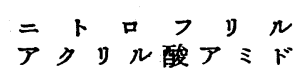 & $0.01 \%$ & 6.6 & 40 & 淡黄色 & 透 明 & \\
\hline & ソルビン酸ナトリウム & $0.4 \%$ & 6.8 & 40 & 落葉色 & 微 濁 & \\
\hline \multirow{7}{*}{$\begin{array}{l}\text { Benzalkonium } \\
\text { chloride }\end{array}$} & 対 & な し & 6.4 & 52 & 無 色 & 透 明 & \multirow{4}{*}{$\begin{array}{l}\text { 無 } \\
\text { ホル } \\
\text { ホルマンン臭 } \\
\text { アルュール臭 }\end{array}$} \\
\hline & 䂽 & $0.5 \%$ & 8.6 & 52 & $\prime \prime$ & $\prime \prime$ & \\
\hline & ホルムアルデヒド & $0.1 \%$ & 6.4 & 52 & $" \prime$ & " & \\
\hline & $ア ル コ-ル$ & $10 \%$ & 6.2 & 52 & $\prime \prime$ & $\prime \prime$ & \\
\hline & 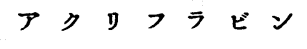 & $0.3 \%$ & 6.4 & 52 & 茶褐色 & 微 濁 & 無 \\
\hline & 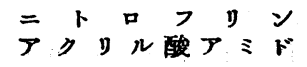 & $0.01 \%$ & 6.4 & 52 & 谈黄色 & 透 明 & $\prime \prime$ \\
\hline & ソルビン酸ナトリウム & $0.4 \%$ & 6.8 & 52 & 落葉色 & $\prime \prime$ & " \\
\hline
\end{tabular}


これ等の結果より見て菌の発育阻止目的に添加物とし て利用出来る可能性のあるものは, 砋砂, ホルムアルデ \&ド, アルコール, アクリフラビン，ニトロフリルアク
リル酸アミド及びソルビン酸ナトリウム等であろう。

\section{V. 薬物添加後の逆性石醶の性状}

a) 実験法

表 5 莱物添加後の有機物共存下における殺菌作用 (1)

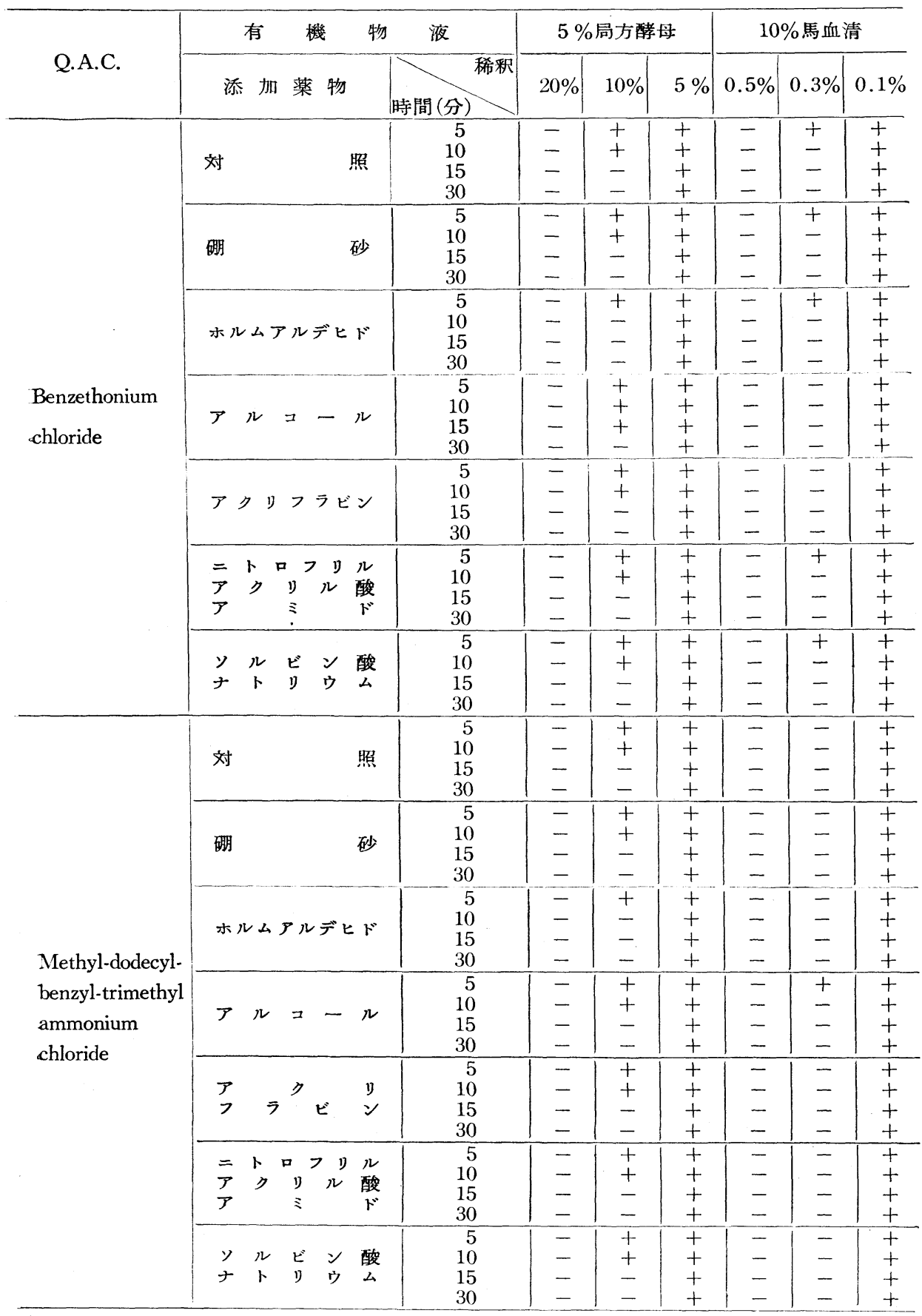


表 5 莱物添加後の有機物共存下における殺菌作用 (2)

\begin{tabular}{|c|c|c|c|c|c|c|c|c|}
\hline \multirow{2}{*}{ Q.A.C. } & \multicolumn{2}{|l|}{ 機 } & \multicolumn{3}{|c|}{5 \%局方酵母 } & \multicolumn{3}{|c|}{ 10\%馬血清 } \\
\hline & 添 加 薬 物 & 時間(分) & $5 \%$ & $3 \%$ & $1 \%$ & $0.5 \%$ & $0.3 \%$ & $0.1 \%$ \\
\hline \multirow{7}{*}{$\begin{array}{l}\text { Benzalkonium } \\
\text { chlolide }\end{array}$} & 対 & $\begin{array}{r}5 \\
10 \\
15 \\
30 \\
\end{array}$ & $\begin{array}{l}- \\
- \\
-\end{array}$ & $\begin{array}{l}+ \\
+ \\
- \\
-\end{array}$ & $\begin{array}{l}+ \\
+ \\
+ \\
+\end{array}$ & $\begin{array}{l}- \\
- \\
-\end{array}$ & $\begin{array}{l}+ \\
- \\
-\end{array}$ & $\begin{array}{l}+ \\
+ \\
+ \\
+\end{array}$ \\
\hline & 䂽 & $\begin{array}{r}5 \\
10 \\
15 \\
30\end{array}$ & $\begin{array}{l}- \\
- \\
-\end{array}$ & $\begin{array}{l}+ \\
+ \\
-\end{array}$ & $\begin{array}{l}+ \\
+ \\
+ \\
+\end{array}$ & $\begin{array}{l}- \\
- \\
-\end{array}$ & $\begin{array}{l}+ \\
- \\
-\end{array}$ & $\begin{array}{l}+ \\
+ \\
+ \\
+\end{array}$ \\
\hline & ホルムアルデヒド & $\begin{array}{r}5 \\
10 \\
15 \\
30 \\
\end{array}$ & $\begin{array}{l}- \\
\overline{-} \\
-\end{array}$ & $\begin{array}{l}+ \\
+ \\
-\end{array}$ & $\begin{array}{l}+ \\
+ \\
+ \\
+\end{array}$ & $\begin{array}{l}- \\
- \\
-\end{array}$ & $\begin{array}{l}+ \\
- \\
-\end{array}$ & $\begin{array}{l}+ \\
+ \\
+ \\
+\end{array}$ \\
\hline & $ア ル コ-ル$ & $\begin{array}{r}5 \\
10 \\
15 \\
30 \\
\end{array}$ & $\begin{array}{l}- \\
\overline{-} \\
-\end{array}$ & $\begin{array}{l}+ \\
+ \\
-\end{array}$ & $\begin{array}{l}+ \\
+ \\
+ \\
+\end{array}$ & $\begin{array}{l}- \\
- \\
-\end{array}$ & $\begin{array}{l}t \\
- \\
-\end{array}$ & $\begin{array}{l}+ \\
+ \\
+ \\
+\end{array}$ \\
\hline & アクリフラビン & $\begin{array}{r}5 \\
10 \\
15 \\
30\end{array}$ & $\begin{array}{l}- \\
- \\
-\end{array}$ & $\begin{array}{l}+ \\
+ \\
-\end{array}$ & $\begin{array}{l}+ \\
+ \\
+ \\
+\end{array}$ & $\begin{array}{l}- \\
- \\
-\end{array}$ & $\begin{array}{l}- \\
\overline{-} \\
-\end{array}$ & $\begin{array}{l}+ \\
+ \\
+ \\
+\end{array}$ \\
\hline & 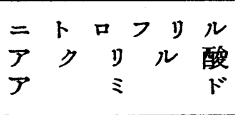 & $\begin{array}{r}5 \\
10 \\
15 \\
30\end{array}$ & $\begin{array}{l}- \\
\overline{-} \\
-\end{array}$ & $\begin{array}{l}+ \\
+ \\
- \\
-\end{array}$ & $\begin{array}{l}+ \\
+ \\
+ \\
+\end{array}$ & $\begin{array}{l}- \\
- \\
-\end{array}$ & $\begin{array}{l}- \\
- \\
-\end{array}$ & $\begin{array}{l}+ \\
+ \\
+ \\
+\end{array}$ \\
\hline & $\begin{array}{lllll}\text { ソ } & ル & \text { ビ } & \searrow & \text { 酸 } \\
\text { ナ } & ト & \mathfrak{y} & \text { ウ } & 厶\end{array}$ & $\begin{array}{r}5 \\
10 \\
15 \\
30\end{array}$ & $\begin{array}{l}- \\
\overline{-} \\
-\end{array}$ & $\begin{array}{l}+ \\
+ \\
-\end{array}$ & $\begin{array}{l}+ \\
+ \\
+ \\
+\end{array}$ & $\begin{array}{l}- \\
- \\
-\end{array}$ & $\begin{array}{l}+ \\
- \\
-\end{array}$ & $\begin{array}{l}+ \\
+ \\
+ \\
+\end{array}$ \\
\hline
\end{tabular}

前項で決定した薬物を夫从三種 Q.A.C. に添加し，そ の添加後の水素イオン濃度, 石炭酸係数, 色調, 透明 度, 臭気等の变化の有無を対照と比較した。

添加量は硼砂 $0.5 \%$ ，ホルムアルデヒド $0.1 \%$ ，アル

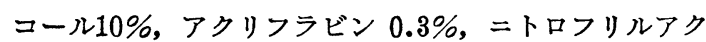
リル酸アミド $0.01 \%$ ，ソルビン酸ナトリウム $0.4 \%$ 割 にした。

又水素イオン濃度の測定には呈色法を利用し, 石炭酸 係数の測定には衙生検查指針中の消毒薬検查指針に準拠 して行った。同時に有機物共存下では Q.A.C.の殺菌効 力は低下するが, その低下の度合を無添加のものと比較 した。使用した有機物は $\mathbf{5} \%$ 割に浮遊した局方乾燥母 醅と10\%の割に稀釈した馬血清とを用い，乙の浮遊液 5 ccにブイヨン培養チフス菌を $1 \mathrm{cc}$ 加え, 更に所定濃度の Q.A.C. 液を 5 cc 注加して, 後培盖を 5 分, 10 分, 15 分, 30 分と行い，殺菌の有無を判定した。

表 5 中の Q.A.C. の濃度は10\% Q.A.C. (市販品と同一 濃度)学原液と考元，これょりの稀釈度を示している。

b) 実験成績

成績は表 4 亿示す通り，水素イオン濃度はいずれの場 合も対照に比較して硼砂がやや高くなるのが見られた以
外，ほとんど変化は見られなかった。石炭酸係数も対照 に比して変化なく，薬物添加による影響はないと云って 良かろう。

色調及び透明度は硼砂，ホルムアルデヒド，アルコー ルを加えた場合には対照と全く変化なく, 無色, 水様透 明であり，アクリフラビンは茶褐色，ニトロフリルアク リル酸アミドは淡黄色, ソルビン酸ナトリウムは落葉色 を帯びる。ニトロフリルアクリル酸アミドは呈色する も, 透明であるが,ソルビン酸ナトリウムは B A C に添加 したときには透明であったが，B T C，M D B A Cに加 えた場合は僅かに混濁した。アクリフラビンは何れの場 合にも僅かに混濁が認められた。

Q.A.C. は臭気が鿌とんごないものであるが，アルコ ールとホルムアルデヒドを加えた場合には夫々特有の臭 気を帯びる。その他のものでは無臭であり, 対照と比較 して変化が見られなかった。

有機物共存下の 殺菌効力の 成績は 表 5 に 示す如く, 醭母浮遊液に加える Q.A.C. の濃度は， B T C及びMD B A Cでは $20 \% ， 10 \% ， 5 \%$ とし，B A Cの場合には 5 \%, 3\%, 1\%とした。その結果， B T C並びにMD B A C Kホルムアルデヒドを加えた場合には殺菌效力はや 
や増強し， B T Cにアルコールを加えると僅かに減退す る結果が見られたが, 他の場合には, 何れの Q.A.C.に 䪤物を加えても対照上比較して変化が全く見られなかっ た。

馬血清を有機物として使用した場合には， B T Cにア ルコール, アクリフラビンを加えた場合, 殺菌効果は僅 かに增し，MD B A Cの場合ではアルコールを加えると 僅かに減退した。他の薬物の添加では対照と比較して変 化が見られなかった。BACに添加したものではアクリ フラビン，ニトロフリアクリル酸アミドのときに僅かに 増加しているのが見られた。しかし, 何れの場合に打い てもその変化は僅少であって, Q.A.C. に薬物を添加し た際の有機物共存下の殺菌効力の低下度は対照とほとん ぞ同一で，添加の影響はないと考えられる。

\section{VI. 考 察}

Loubury $^{11}$ が Q.A.C. より Pseudomonas pyocyanea を検出したのが生菌分離の始めであって, Molner ${ }^{19}$ が その後, 牛乳中より Q.A.C. によって殺菌されない同種 の菌を見出した。Anderson \& Keynes ${ }^{201}$ はコルク栓の浸 出液を原因々考えて種队の実験を行い, Hornung ${ }^{21}$, Nage $^{22)}$ 等は結核菌に対して殺菌効力をもたないととを 述べて抢るが，Pierce ${ }^{23}$ 等は $1 \%$ Q.A.C. は結核菌を 完全に殺菌すると報告している。中野 ${ }^{13)}$ は Alcaligenes 及び Achromobacter に属する菌が Q.A.C. 中でこれを 栄養源として発育することを始めて見出した。これ等の 細菌恃芳香族系統の消毒薬にはチフス菌と湾とんど同様 な感受性を有し, Q.A.C. は大きな長所がある反面, 他 の消毒薬に見られない短所を有することが判明した。 Loubury 等の分離した菌も或いは Q.A.C. 中で発育する のではなかろろかと推察される。

British Medical Journal ${ }^{12)}$ 紙上に注 Pseudomonas pyocyanea が Q.A.C. 中に見出されるととがあり，菌血症 に感染する危険があるから注意せよとの主旨の一交が見 られるが,この対策としては僅かに瓶を加熱するか,コル ク栓に注意することなどを述べている他炕，㹸とんど 対策らしい対策もとられて扔らず，外装品殺菌の問題よ りもこの場合はむしろ内容に問題があるととが明確にな ったのであるから,加熱老するならば, Q.A.C. 自体を加 熱し, 生菌の存在を防止しなくてはならない。実際加熱 によって Q.A.C. 中の菌は $60^{\circ} \mathrm{C}$ 数秒保てば死滅して了 ろが，Q.A.C. 自体は何等の変化も見られないので，再 污染の可能性並びに相当大量を処理する繁雑さを考えな ければ最も良い方法である。しかし再污染があれば，菌
は增殖する可能性が大きく, 加熱は完全な方法とは云い 難い。著者は積極的にこれ等の菌の発育或は生菌の存在 を不能にさせなければならないと考え, Q.A.C. に添加 して殺菌力や発育阻止力を増加学たは附加せしめ得る薬 物を求めたところ, 硼砂, ホルムアルデヒド, アルコー ル, アクリフラビン， =トロフリルアクリル酸アミド, ソルビン酸ナトリウムの 6 種が得られた。硼砂は安息香 酸ナトリウムと共用して塩魚をつくる時に用いられてい ると Feller ${ }^{24)}$ 等は報告している。本品は弱アルカリ性て あり, 弱いが殺菌力を有して掠り，てれを $0.5 \%$ に添加 した Q.A.C. は僅かに水素イオン濃度がアルカリ性とな るが, 石炭酸係数, 有機物共存下の殺菌効力, 色調, 透 明度, 臭気等は全く無添加のものと変らず最も有望なも のと考える。

ホルムアルデヒドは特有な臭気を帯びるがこれを問題 にしなければ人体に対して許可されている濃度 ${ }^{25}$ 以下で 充分な効力を有する。

アルコールは10\%の添加であるから, 何等問題となる 点はないものと考える。アクリフラビンはアクリデン色 素の一種であり, 創傷等の場合に使用されて殺菌効力を 有するが, Q.A.C. に加えた場合に着色が強く, 特殊な 用途に用いられるのみであり, 又僅かに混濁するのであ まり良好なむのとは云い難い。ニトロフリルアクリル酸 アミドはやや淡黄色を帯びる程度でしかも, 比較的少量 で有効であるために使用して良いものではなかろうか。 ソルビン酸ナトリウムは淡い着色と, 混濁する場合があ るため避けた方が良いと考える。

従って著者は Q.A.C.には硼砂，ニトロフリルアクリ ル酸アミド，アルコールヌはホルムアルデヒドを添加す べきととを提唱したい。

\section{VII. 結 び}

1. 逆性石觶を栄盖源として增殖する細菌はプイヨン 培地中では比較的熱抵抗性注強く, $50^{\circ} \mathrm{C} て ゙ も 24$ 封間経過 後も菌は生存するが, 逆性石龄液中では数秒以内に死隇 し, 污染の疑いがある時には加熱によって短時間で容易 に殺菌し得る。

2. 分離された Alcaligenes 及び Achromobacter に 属する細菌恃芳香族消毒薬に対してチフス菌とほとんど 同様な感受性导有する。

3. 加熱により無菌となった逆性石龆液む再污染に対 しては安全であり得ず，てれを防止するために数種の楽 物学逆性石䍄加合成培地に添加して発育阻止力等より有 効なものを選んだ。ついで逆性石缿夜に，選び出した薬 
物を添加し，性状並びに殺菌効力の変化を調べた。

4. 逆性石嗝液中の生菌発育を防止するためには 0.5 $\%$ 割に硼砂を加えるか， $0.01 \%$ そトロフリルアクリ ル酸アミド，0.06\%にホルムアルデヒド，或は $10 \%$ 割 にアルコールを加えれば良いものと考えられる。

稿を終るに臨み，終始御愁篤な御指首並びに御校閲の 労を賜 りました国立予防衛生研究所細菌部長福見秀雄博 士, 東邦大学教授桑原章吾博士並びに予研細菌部藤本進 博士に深甚なる感謝の意を表わします。なま本実験の実 施に当り多大の労を得ました中野要子技官他研究室員に 厚く御礼申上げますと共に御便宜を的計り項きました逆 性石敛協会下感謝致します。

\section{参考文献}

1) Domagk, G. : Deut. Med. Wochoshr., 61, 829 $-831,1935$.

2) Penniston, V. J. and Hedrick, L. R. : Science, 101, 362-363, 1945.

3) Hucker, R. F. et al. : Food Technol., 1, 321$344,1947$.

4) Wetzel, U. : Arch. Hyg. u. Bact., 114, 1, 1935.

5) Barnes, J. M. : Lancet, 242, 531-532, 1942.

6) Williams, R. et al. : Lancet, 1, 522-526, 1943.

7) Gardner, A. D. and Seddon, H. J. : Lancet, 250, 683-686, 1946.

8) Ezickson, W. J. : Jour. Urol., 54, 235-240, 1945.
9) Lowsley, O. S. et al. : Jour. Urol., 59, 966969, 1948.

10) Mohler, R.W. and Bishop, E. H. : Am. Jour. Obst. Gynecol., 50, 489-495, 1945.

11) Loubury, E. J. L. : Brit. Jour. Indust. Med., 8, 22-25, 1951.

12) Attention "Bacteria in Antiseptic Solutions": Bris. Bed. Jour., 16, 438, 1958.

13）中野要子：日本細菌学会雑誌，15，12，1960。（揭 載予定)

14）相磯和嘉：腐研報 9，1-25，1956；腐研報， 10 , $87-96,1957$.

15) Spanswick, M. P. : Amer. Jour. Pab. Health, 20, 73-74, 1930.

16) Haines, R.B. : Jour. Hyg.; 33, 175-182, 1933.

17) Bergey's Manual of Determinative Bacteriology. 7 th Ed.

18) Lovell, D. L. : Arch. Surg., 53, 304, 1946.

19) Molner, N. M. : Fine Organic, Inc. (未発表)

20) Anderson, K. \& Keynes, R. : Brit. Med. Jour., 2, 274-275, 1958.

21) Hornung, H. : Z. Immunit., 84, 119-135, 1935

22) Nagel, A. : Münch, Med. Wochenschr., 36, 970-972, 1940.

23) Pierce, M.E. and Tilden, E. B. : Jour. Bact., 51, 42-43, 1946.

24) Fellers, C.R. and Harvey, E. W. : Food Res., 5, 1, 1940. (McCulloch: : Disinfection and Sterilization 2 ed. 1946 よ $\emptyset$ )

25）厚生省編生物学的製削規準，1960.

（受付：1960 年 11 月 28 日） 